\title{
Analisis Kematian Larva Nyamuk Aedes agypti Akibat Pemberian Perasan Buah Nanas (Ananas comosus)
}

\author{
Victoria Ire Tominik ${ }^{1}$, Margareta Haiti ${ }^{2}$ \\ ${ }^{1,2}$ Program Studi Analis Kesehatan, Universitas Katolik Musi Charitas Palembang, Indonesia \\ Email: tominikvictoriaire@gmail.com
}

\begin{abstract}
Analysis of Pineapple (Ananas comosus) on the Death of Aedes agypti Mosquitoe Larvae. South Sumatra including 11 provinces experienced outbreaks. Aedes agypti is the main vector of dengue fever. Eradication by breaking the life cycle of Aedes agypti (larvae) mosquitoes which are not a health risk and environmentally friendly. Pineapple grows a lot in Indonesia, especially South Sumatra. Bromelin is an enzyme in pineapple which hydrolyzes peptide bonds in the protein content to amino acids. Parts of pineapple meat are used more while the skin and humps are wasted. Objective: to determine the effect of variations in concentration $(100 \%, 75 \%$, $50 \%, 25 \%$ ) of pineapple juice (skin, meat, hump/stem) and the time of the death of Aedes agypti mosquito larvae. Research method: pure experimental, June-July 2018. The research subjects were 3000 Aedes agypti instar III larvae, population 2404 larvae, 2100 larvae samples, simple sampling random. Analysis of Pearson test data, One Way Anava test, post hoc LSD and post hoc Duncan, 95\% confidence level. There was a relationship between the variation of pineapple juice concentration and larvae mortality with a sig (2-tailed) value of 0.001 , insignificant meat and skin but skin and hump/stem or meat and hump/stem are significantly different from the number of mosquito larvae deaths in the first 12 hours of meat 97,67\%, skin 96,83\%, humps $87,17 \%$. The higher the concentration of the more deaths of Aedes agypti mosquito larvae with the skin part has the same ability as meat and better than hump.
\end{abstract}

Keywords: Concentration, Pineapple, Time of death

\begin{abstract}
Abstrak: Analisis Perasan Buah Nanas (Ananas comosus) terhadap Kematian Larva Nyamuk Aedes agypti. Sumatera Selatan termasuk 11 propinsi mengalami KLB. Aedes agypti merupakan vektor utama demam berdarah. Pemberantasan dengan memutus siklus hidup nyamuk Aedes agypti (larva) yang tidak beresiko kesehatan dan ramah lingkungan. Buah nanas banyak tumbuh Indonesia terutama Sumatera Selatan. Bromelin merupakan enzim dalam nanas yang menghidrolisis ikatan peptida pada kandungan protein menjadi asam amino. Bagian daging buah nanas lebih banyak digunakan sementara kulit dan bonggol/batang terbuang sia-sia. Tujuan penelitian: mengetahui dampak variasi konsentrasi $(100 \%, 75 \%, 50 \%, 25 \%)$ perasan nanas (kulit, daging, bonggol/batang) dan waktu kematian larva nyamuk Aedes agypti. Metode penelitian: eksperimental murni, Juni-Juli 2018. Subyek penelitian 3000 larva Aedes agypti instar III, populasi 2404 larva, sampel 2100 larva, random simple sampling. Analisis data uji Pearson,uji One Way Anava,post hoc LSD dan post hoc Duncan, tingkat kepercayaan 95\%. Ada hubungan antara variasi konsentrasi perasan buah nanas dengan kematian larva dengan nilai sig (2-tailed) 0,001, antara daging dan kulit tidak signifikan tetapi kulit dan bonggol atau daging dan bonggol beda signifikan dengan jumlah kematian larva nyamuk pada 12 jam pertama daging 97,67\%, kulit 96,83\%, bonggol $87,17 \%$. Semakin tinggi konsentrasi semakin banyak kematian larva nyamuk Aedes agypti dengan bagian kulit memiliki kemampuan sama baik dengan daging dan lebih baik dari bonggol.
\end{abstract}

Kata kunci: Konsentrasi, Nanas, Waktu kematian

Penyakit demam berdarah (DBD) banyak dijumpai di Indonesia dan sering menimbulkan kejadian luar biasa (KLB). Menurut Kemenkes (2015), demam berdarah dengue merupakan penyakit yang disebabkan oleh virus Dengue yang ditularkan dari orang ke orang melalui gigitan nyamuk Aedes (Ae). Ae aegypti merupakan vektor yang paling utama. Nyamuk dengue ini terdapat hampir di seluruh pelosok Indonesia. Direktorat Pengendalian Penyakit Tular Vektor dan Zoonosis Kementerian Kesehatan menyebutkan hingga akhir Januari (Kemenkes, 2016a), dilaporkan bahwa Propinsi Sumatera Selatan termasuk dari 11 propinsi yang mengalami kejadian luar biasa (KLB) penyakit demam berdarah. Pencegahan demam 
berdarah yang paling efektif dan efisien adalah kegiatan Pemberantasan Sarang Nyamuk (PSN) dengan cara 3M Plus, yaitu: 1) Menguras, 2) Menutup, 3) Memanfaatkan kembali atau mendaur ulang barang bekas dengan Plus adalah segala bentuk kegiatan pencegahan, seperti: 1) Menaburkan bubuk larvasida, 2) Menggunakan obat nyamuk atau anti nyamuk; 3) Menggunakan kelambu saat tidur; 4) Memelihara ikan pemangsa jentik nyamuk; 5) Menanam tanaman pengusir nyamuk; 6) Mengatur cahaya dan ventilasi dalam rumah; 7) Menghindari kebiasaan menggantung pakaian di dalam rumah (Kemenkes, 2016.b). Kepedulian masyarakat terhadap kebersihan lingkungan sekitarnya menjadi kunci penanggulangan kasus penyakit demam berdarah dengue. Intervensi pemerintah akan sia-sia tanpa ada kesadaran masyarakat memberantas sarang nyamuk.

Peraturan Menteri Kesehatan RI nomor 374/Menkes.Per/III/2010 tentang pengendalian vektor. Pengendalian vektor adalah semua kegiatan atau tindakan yang ditujukan untuk menurunkan populasi vektor serendah mungkin sehingga keberadaannya tidak lagi berisiko untuk terjadinya penularan penyakit tular vektor di suatu wilayah atau menghindari kontak masyarakat dengan vektor sehingga penularan penyakit tular vektor dapat dicegah. Penelitian yang dilakukan oleh Tamza dkk (2013) menunjukkan ada hubungan antara keberadaan jentik Aedes aegypti pada tempat penampungan air, menguras tempat penampungan air, dan penggunaan obat anti nyamuk siang-malam dengan kejadian demam berdarah. Artinya pengendalian demam berdarah dilakukan dengan memutus rantai penularan vektor baik secara kimia seperti penyemprotan insektisida, penggunaan abate dan temephos, secara biologi seperti penggunakan predator (bakteri) atau menggunakan tanaman, dan juga secara fisik dengan menerapkan manajemen lingkungan bersih. Pencegahan paling efektif dan efisien adalah pemberatasan sarang nyamuk (PSN) membunuh larva nyamuk, dengan menaburkan bubuk larvasida beresiko terhadap kesehatan sehingga diperlukan cara-cara yang lebih alami dan ramah lingkungan.

Nanas merupakan salah satau buah yang banyak tumbuh di seluruh wilayah Indonesia terutama di Sumatera Selatan. Produksi nanas di Indonesia rata-rata 542.856 ton/tahun (Irawan et al.,2014). Masyarakat Sumatera pada umumnya seperti Jambi. Bengkulu, Lampung termasuk Sumatera Selatan tidak hanya mengkonsumsi buah nanas sebagai buah melainkan sudah menjadi salah satu kebutuhan utama dalam setiap masakan terutama pindang. Dalam mengkonsumsi buah nanas (Ananas comosus) oleh masyarakat lebih banyak mengambil bagian daging buah nanas untuk dikonsumsi sementara bagian kulit dan bonggol/batang masih sedikit dimanfaatkan masyarakat bahkan lebih sering terbuang sia-sia sebagai sampah basah.

Kompsisi buah nanas mengandung vitamin A, kalsium, fosfor, magnesium, besi, natrium, kalium, dekstrosa, sukrosa (gula tebu), dan enzim bromelin dimana 95\% merupakan campuran protease sistein, yang dapat menghidrolisis protein (proteolisis) dan tahan panas (Silaban I, dan Rahmanisa.S, 2016). Setengah dari protein dalam nanas mengandung protease bromelin (Wuryanti, 2004). Bromelin adalah enzim yang berkhasiat sebagai anti radang. Enzim bromelin merupakan proteolitik yang dapat menghidrolisa protein, protease atau peptide sehingga dapat digunakan untuk melunakkan daging, mengganggu pertumbuhan sel kanker, menghambat agregasi platelet, mempunyai aktivitas fibrinolitik (Wibisono, 2011). Enzim bromelin merupakan enzim yang dapat menghidrolisis ikatan peptida pada kandungan protein menjadi asam amino. Enzim bromelin memiliki sifat yang mirip dengan enzim proteolitik, yakni memiliki kemampuan untuk menghidrolisis protein lainnya, seperti enzim rennin (renat), papain, dan fisin (Ishak, 2012). Limbah buah nanas beberapa diantaranya seperti kulit sebesar 56\% kulit, bonggol 7\% dan lain sebagainya (Oktaviani R. et al., 2016).

Permasalahan yang muncul adalah bagaimana cara membasmi nyamuk dengan memutus siklus hidup larva nyamuk melalui cara aman bagi kesehatan manusia dan ramah lingkungan melalui pemanfaatan limbah kulit dan bonggol nanas. Tujuan penelitian ini adalah ingin mengetahui pengaruh perasan bagian buah nanas (kulit, daging, bonggol/batang), variasi konsentrasi $(100 \%, 75 \%, 50 \%, 25 \%)$ dan waktu pemberian terhadap kematian larva.

\section{METODE}

Penelitian eksperimental murni dengan desain post test only control group design untuk mengidentifikasi variasi konsentrasi (100\%, $75 \%, 50 \%, 25 \%)$ perasan dari bagian buah nanas (kulit, daging dan bonggol) dan waktu pemberian yang dapat mengakibatkan kematian. Waktu penelitian dari pembiakkan hingga larva instar III kemudian dilakukan perlakuan terhadap larva dengan berbagai konsentrasi 
$(100 \%, 75 \%, 50 \%, 25 \%)$ perasan kulit, daging dan bonggol/batang buah nanas dengan waktu pengamatan selama 12 jam, 24 jam dan 36 jam, dilakukan bulan Juni sampai Juli 2018.

Penelitian ini didanai oleh Kemenristekdikti melalui Hibah Penelitian Dosen Pemula (PDP) dengan Kontrak Penelitian Tahun Anggaran 2018 Nomor: 106/SP2H/LT/DRPM/2018.

Lokasi pembiakkan, perlakuan hingga pengamatan di Lokalitbang P2B2 Baturaja Sumatera Selatan. Target penelitian adalah mengetahui kematian larva Aedes agypti setelah diberi perlakuan perasan air nanas. Subyek penelitian larva Aedes agypti instar III yang telah memenuhi kriteria inklusi dan eksklusi.

Dari pembiakkan hingga mencapai tahap larva instar III lalu sebanyak 3000 larva, dilakukan pemilihan sesuai kriteria inklusi dan ekslusi sebanyak 2404 larva (uji kualitatif) sebagai populasi dan jumlah sampel yang digunakan menggunakan rumus Federer: $(\mathrm{t}-1)(\mathrm{n}$ 1) $\geq 15$ sehingga ditetapkan jumlah pengulangan sebanyak 6 kali dari kelompok variasi konsentrasi $(100 \%, 75 \%, 50 \%, 25 \%)$ dan bagian buah nanas (kulit, daging dan bonggol) sehingga didapatkan 14 kelompok yang meliputi 12 kelompok perlakuan buah nanas ditambah 1 kelompok kontrol positif dan 1 kelompok kontrol negatif dengan masing-masing berisi 25 larva instar III. Total jumlah sampel yang digunakan sebanyak 2100 larva yang meliputi 1800 larva dilakukan perlakuan air perasan nanas (Ananas comosus), 150 larva kontrol positif dan 150 larva kontrol negatif. Tehnik sampel yang digunakan Random simple Sampling. Bagian buah nanas dipisahkan antara kulit, daging dan bonggol lalu di juice ekstractor untuk memisahkan antar ampas dan air perasan kemudian air perasan dilakukan penyaringan sebanyak 3 kali sehingga dipastikan tidak ada ampas yang mengikuti selanjutnya dibuat berbagai konsentrasi seperti $100 \%$ (murni tanpa penambahan aquabides), sementara $75 \%, 50 \%$ dan $25 \%$ diberi tambahan aquabides. Kontrol positif mengunakan campuran abate $1 \%$ dan kontrol negatif hanya aquabides saja.

Data yang didapat berupa jumlah kematian larva nyamuk Aedes agypti instar III setelah 12 jam, 24 jam, dan 36 jam perlakuan diberikan berbagai konsetrasi $(100 \%, 75 \%, 50 \%$, $25 \%$ ) dan bagian buah nanas (kulit, daging dan bonggol). Data dianalisis menggunakan taraf signifikan $(\rho)$ yang digunakan adalah $5 \%$ $(\alpha=0,05)$ meliputi uji normalitas, uji homogenitas, uji Pearson, uji One way anava, uji post hoc LSD dan uji post hoc Duncan (Dahlan,
2014) untuk mengetahui pengaruh pada konsentrasi dan bagian mana dari buah nanas yang memiliki dampak kematian larva Aedes agypti instar III paling tinggi.

\section{HASIL}

Hasil yang diperoleh berdasarkan dampak variasi konsentrasi $(100 \%, 75 \%, 50 \%, 25 \%)$ dan bagian dari buah nanas (kulit, daging, bonggol/batang) dan waktu pemberian yang mengakibatkan kematian larva nyamuk Aedes agypti secara keseluruhan terjadi di 36 jam setelah pemberian perasan nanas, seperti tabel berikut:

\section{Kematian Larva Nyamuk Aedes agypti Setelah Pemberian Berbagai Variasi Konsentrasi Air Perasan Buah Nanas Setelah 12 jam, 24 jam, dan 36 jam Perlakuan}

Hasil analisis dari 1800 larva nyamuk Aedes agypti yang diberi variasi konsentrasi $(100 \%, 75 \%, 50 \%, 25 \%)$ air perasan buah nanas dengan masing-masing variasi sebanyak 450 larva atau rata-rata 150 larva terjadi kematian larva setelah 12 jam, 24 jam dan 36 jam pemberian seperti tabel 1 berikut:

Tabel 1. Kematian Larva Nyamuk Aedes agypti Setelah Pemberian Variasi Konsentrasi Air Perasan Nanas (Ananas comosus) Selama 12 jam, 24 jam dan 36 jam

\begin{tabular}{lcrr}
\hline Konsentrasi & Waktu & \multicolumn{2}{c}{ Kematian Larva } \\
& Kematian & Rata-rata & \multicolumn{1}{c}{$\%$} \\
\hline $100 \%$ & 12 Jam & 150 & 100 \\
& 24 Jam & 0 & 0 \\
$75 \%$ & 36 Jam & 0 & 0 \\
& 12 Jam & 150 & 100 \\
& 24 Jam & 0 & 0 \\
$50 \%$ & 36 Jam & 0 & 0 \\
& 12 Jam & 149 & 99,33 \\
& 24 Jam & 1 & 0,67 \\
$25 \%$ & 36 Jam & 0 & 0 \\
& 12 Jam & 114 & 76,00 \\
& 24 Jam & 23 & 15,33 \\
& 36 Jam & 13 & 8,67 \\
\hline
\end{tabular}

Berdasarkan tabel 1, tampak bahwa dalam 12 jam setelah pemberian pada konsentrasi $100 \%$ dan $75 \%$ terjadi kematian seluruh larva sebanyak $100 \%$, konsentrasi $50 \%$ terjadi kematian 99,33\% dan kematian 100\% setelah 24 jam perlakuan serta konsentrasi $25 \%$ terjadi kematian larva sebanyak $76,00 \%$ dan mencapai kematian $100 \%$ setelah 36 jam pemberian. 
Kematian Larva Nyamuk Aedes agypti Setelah Pemberian Air Perasan Bagian Buah Nanas Setelah 12 jam, 24 jam, 36 jam Perlakuan

Hasil analisis dari 1800 larva nyamuk Aedes agypti yang diberi air perasan bagian buah nanas (kulit, daging, bonggol/bantang) dengan masing-masing variasi 600 larva atau rata-rata 150 larva terjadi kematian larva setelah 12 jam, 24 jam dan 36 jam pemberian seperti tabel 2 berikut:

Tabel 2.Jumlah dan Persentase Kematian Larva Nyamuk Aedes agypti Setelah Pemberian Air Perasan Bagian Buah Nanas Selama 12 jam, 24 jam dan 36 jam

\begin{tabular}{lrrr}
\hline \multirow{2}{*}{ Konsentrasi } & Waktu & \multicolumn{2}{c}{ Kematian Larva } \\
\cline { 3 - 4 } & Kematian & Rata-rata & \multicolumn{1}{c}{$\%$} \\
\hline Kulit & 12 Jam & 145 & 96,83 \\
& 24 Jam & 4 & 2,33 \\
\multirow{3}{*}{ Daging } & 36 Jam & 1 & 0,84 \\
& 12 Jam & 147 & 97,67 \\
& 24 Jam & 1 & 0,33 \\
Bonggol/Batang & 36 Jam & 3 & 2,00 \\
& 12 Jam & 131 & 87,17 \\
& 24 Jam & 12 & 8,83 \\
& 36 Jam & 6 & 4,00 \\
\hline
\end{tabular}

Berdasarkan Tabel 2, tampak setelah 12 jam pemberian air perasan kelompok bagian daging buah nanas terjadi kematian larva sebanyak 97,67\%, kelompok bagian kulit $96,83 \%$, dan kelompok bagian bonggol/batang $87,17 \%$. Kematian secara keseluruhan $100 \%$ pada ketiga kelompok perlakuan (daging, kulit, bonggol/batang) terjadi setelah 36 jam pemberian. Hasil uji statistik meliputi uji normalitas, uji homogenitas dinyatakan berdistribusi normal dan homogen, uji korelasi Pearson dinyatakan ada korelasi signifikan dengan nilai sig (2-tailed) 0,001, uji komparasi one way anava dinyatakan ada perbedaan dengan nilai sig 0,000 tampak pada tabel 3 dan table 4 berikut:

Tabel 3. Uji One Way Anova Variasi Konsentrasi Perasan Nanas dengan Waktu Kematian

\begin{tabular}{lccccc}
\hline \multicolumn{5}{c}{ Anova } \\
\hline Waktu Kematian & \multicolumn{4}{c}{ Mean } \\
& $\begin{array}{c}\text { Sum of } \\
\text { Squares }\end{array}$ & $d f$ & Square & F & Sig. \\
\hline $\begin{array}{l}\text { Between } \\
\text { Groups }\end{array}$ & 492.056 & 3 & 164.019 & 22.134 & .000 \\
\hline
\end{tabular}

\begin{tabular}{llll}
\hline Within & 503.889 & 68 & 7.410 \\
Groups & & & \\
\hline Total & 995.944 & 71 & \\
\hline
\end{tabular}

Hasil uji One way anova antara variasi konsentrasi dengan waktu kematian menunjukkan hasil nilai sig 0,000 . Uji post hoc LSD pada variasi konsentrasi dinyatakan bahwa perbedaan antara konsentrasi $100 \%$ dengan $50 \%$ dan $25 \%$ sementara tidak ada perbedaan antara konsentrasi $100 \%$ dengan $75 \%$. Uji post hoc Duncan didapatkan hasil terdapat dua kolom dimana kolom pertama kelompok konsentrasi $100 \%$ dan kelompok $75 \%$ sementara kolom kedua terdapat kelompok konsentrasi $50 \%$ dan kelompok konsentrasi $25 \%$.

$\begin{aligned} & \text { Tabel 4. Uji One Way Anova Bagian Buah } \\
& \text { Nanas dengan Waktu Kematian }\end{aligned}$
\begin{tabular}{lccccc}
\hline \multicolumn{5}{c}{ Anova } \\
\hline Waktu Kematian \\
\hline $\begin{array}{c}\text { Sum of } \\
\text { Squares }\end{array}$ & df & Square & F & Sig. \\
\hline $\begin{array}{l}\text { Between } \\
\text { Groups }\end{array}$ & 102.194 & 2 & 51.097 & 3.945 & .000 \\
\hline $\begin{array}{l}\text { Within } \\
\text { Groups }\end{array}$ & 893.750 & 69 & 12.953 & \\
\hline Total & 995.944 & 71 \\
\hline
\end{tabular}

Hasil uji One way anova antara bagian buah nanas dengan waktu kematian menunjukkan hasil nilai sig 0,000 . Uji post hoc LSD pada bagian nanas dinyatakan bahwa kelompok kulit dan kelompok daging tidak signifikan, antara kelompok kulit dan kelompok bonggol signifikan, kelompok daging dan kelompok bonggol signifikan. Uji post hoc Duncan didapatkan hasil terdapat dua kolom dimana kolom pertama berisi kelompok kulit dan kelompok daging sementara kolom kedua hanya terdapat kelompok bonggol.

\section{PEMBAHASAN}

Hasil analisis statistik menunjukkan bahwa setiap perlakuan menghasilkan kematian larva nyamuk Aedes agypti yang berbeda-beda dimana semakin tinggi konsentrasi air perasan buah nanas (Ananas comosus) akan semakin banyak jumlah larva dan semakin cepat yang mengalami kematian, hal ini tampak dalam hasil penelitian dimana pada konsentrasi $100 \%$ terjadi kematian secara keseluruhan (100\%) setelah 12 jam pemberian sementara pada konsentrasi $25 \%$ terjadi kematian larva nyamuk $100 \%$ setelah 36 jam pemberian. Penelitian Ellyfas K. dkk (2012) menyatakan bahwa enzim 
bromelin yang dikandung dalam buah nanas akan mendegradasi dan melisiskan dinding kulit larva dan saluran pencernaan larva sehingga larva akan mati. Bromelin dapat mendegradasi kolagen daging, sehingga dapat mengempukan daging (Illanes, 2008). Menurut Ameilia I. dan Herdyastuti N. (2017), menyatakan bahwa nanas yang matang sebagai sumber protease yang tinggi dan bromelin merupakan enzim yang mendegradasi protein dengan cara memutuskan ikatan peptida untuk menghasilkan senyawa yang lebih sederhana. Konsentrasi enzim sebanding dengan kecepatan reaksinya, artinya bila konsentrasi meningkat maka kecepatan reaksinya akan meningkat (Wuryanti, 2006).

Peneliti berpendapat bahwa jumlah kematian larva yang semakin besar dan cepat terjadi pada konsentrasi tinggi disebabkan karena semakin tinggi konsentrasi perasan buah nanas akan semakin tinggi kadar enzim bromelin yang berakibat proses terjadi degradasi ikatan protein dengan cara memutuskan ikatan peptida untuk menjadi lebih sederhana berdampak dinding kulit larva serta saluran pencernaan larva mengalami kehancuran semakin besar dan cepat yang akhirnya menyebabkan jumlah kematian larva nyamuk Aedes agypti semakin besar.

Bagian dari buah nanas (kulit, daging, bonggol) menunjukkan hasil dalam 12 jam setelah pemberian perasan bagian nanas yang menyebabkan kematian larva nyamuk Aedes agypti tertinggi terjadi pada bagian daging dengan jumlah kematian sebesar 97,67\%, diikuti selanjutnya bagian kulit sebesar $96,83 \%$ dan bagian bonggol/batang sebesar 87,17\% . Kematian larva nyamuk Aedes agypti secara keseluruhan (100\%) terjadi di 36 jam Penelitian Oktavia.R, et al., (2013) menyatakan bahwa seluruh bagian buah nanas seperti daging, tangkai, kulit, bonggol/batang, daun mengandung enzim bromelin yang merupakan enzim protease. Murniati (2006) menyatakan bahwa buah nanas yang masih hijau (muda) sedikit mengandung enzim bromelin bila dibandingkan dengan yang sudah matang. dan Supartono (2004) menyatakan bahwa kandungan enzim protease lebih banyak terdapat di bagian daging dari buah nanas matang bila dibandingkan pada bagian lainnya. Penelitian Maryam. S, (2009), bahwa molekul protein (enzim bromelin) yang berada pada batang (bonggol) buah telah ditransportasikan ke bagian daging.

Peneliti berpendapat bahwa jumlah kematian larva tinggi terjadi pada kelompok daging diikuti selanjutnya kelompok kulit dan hasil uji statistik menunjukkan kelompok kulit mempunyai kemampuan membunuh larva sama baiknya dengan daging dan lebih baik dari bonggol. Hal ini disebabkan karena pada buah nanas matang yang ditandai warna kulit buah nanas kuning tua atau orange memiliki kadar enzim bromelin lebih tinggi pada bagian daging dan selanjutnya bagian kulit akibat terjadi pergeseran dari bonggol/batang masuk ke bagian daging dan kulit sehingga kandungan bromelin yang berada dalam bonggol/batang menjadi sedikit. Kadar bromelin yang tinggi mengakibatkan terjadi degradasi ikatan protein dan proses lisis dinding saluran pencernaan larva mengalami kerusakan semakin tinggi yang berakibat jumlah kematian larva menjadi tinggi.

\section{SIMPULAN}

1. Rata-rata jumlah kematian tertinggi larva nyamuk Aedes agypti pada konsentrasi 100\% dan $75 \%$ dalam 12 jam setelah pemberian perasan buah nanas dengan hasil masingmasing sebanyak 150 larva (100\%) diikuti berikutnya konsentrasi 50\% sebanyak 149 $(99,78 \%)$ dengan kematian secara keseluruhan terjadi di 24 jam setelah pembarian. Konsentrasi 25\% terjadi kematian sebanyak 114 larva $(75,78 \%)$ setelah 12 jam pemberian perasan buah nanas dan terjadi kematian secara keseluruhan setelah 36 jam pemberian.

2. Rata-rata jumlah kematian larva nyamuk Aedes agypti tertinggi dalam 12 jam setelah pemberian buah nanas pada bagian daging dari buah nanas (Ananas cosmosus) sebanyak 147 larva (97,67\%), bagian kulit sebanyak 145 larva $(96,83 \%)$ dan bagian bonggol sebanyak 133 larva $(87,17 \%)$. Kematian secara keluruhan terjadi di 36 jam setelah pemberian.

3. Bagian kulit mempunyai kemampuan membunuh larva nyamuk Aedes agypti sama baiknya dengan bagian daging dan lebih baik jika dibandingkan dengan bagian bonggol/batang.

\section{SARAN}

1. Perlu sosialisasi pada masyarakat untuk lebih mengoptimalkan limbah kulit nanas dipergunakan sebagai alternatif membasmi larva nyamuk Aedes agypti sehingga diharapkan kasus demam berdarah dapat ditekan bahkan dihilangkan. 
2. Perlu dilakukan penelitian lebih lanjut pada konsentrasi $100 \%$ dan $75 \%$ dengan waktu yang lebih singkat sehingga didapatkan

\section{DAFTAR PUSTAKA}

Ameilia I. dan Herdyastuti N. 2017, Kitin dari Cangkang Rajungan yang Diperoleh Secara Enzimatik Pada Tahap Deproteinasi.UNESA Journal of Chemistry, 6 (2), 81-85. Retrieved from http://jurnalmahasiswa.unesa.ac.id/index. php/unesa-journal-ofchemistry/article/view/20938

Dahlan. 2014. Statistik Untuk Kedokteran dan Kesehatan: Deskriptif, Bivariat, dan Multivariat. Edisi 6. Epidemiologi Indonesia. Jakarta.

Ellyfas K, Suprobowati OD, Djoko SSBU. 2012. Pengaruh pemberian ekstrak buah nanas (Ananas cosmosus (L) Merr) terhadap kematian larva Aedes agypti. Jurnal Analisis Kesehatan, Vol. 01, No. 2.

Illanes, A. 2008. Enzyme Production. In: Enzyme Biocatalysis: Principles and Applications: Enzyme Production, A. Illanes, Ed. Chile: Springer Pub.

Irawan,J.P, Karno dan Jayadi U. 2014. Pengaruh ekstrak limbah kulit buah nanas Cayenne dalam menurunkan jumlah bakteri Coli pada proses desinfeksi air bersih. Jurnal Widya Warta, No. 01 Tahun XXXV/III/Januari 2014. ISSN: 0654-1981, 96-197.

Ishak,M.C, 2012. Pengaruh Proses Pengeringan dan Imobilisasi Terhadap Aktivitas dan Kestabilan Enzim Bromelain dari Buah Nanas. [Skripsi]. Makasar: Jurusan Teknologi Pertanian Fakultas Pertanian Universitas Hasanudin.

http://repository.unhas.ac.id/handle/ 123456789/1950. Diakses pada 22 Mei 2017.

Kementerian Kesehatan Republik Indonesia. Peraturan Menteri Kesehatan RI. 2015. Demam Berdarah Biasanya Mulai Meningkat.

http://www.depkes.go.id/article/view/150 11700003/demam-berdarah-biasanyamulai-meningkat-di-januari.html.

Diakses pada 10 Juni 2016.

Kementerian Kesehatan Republik Indonesia. Peraturan Menteri Kesehatan RI. 2016.a Wilayah KLB DBD Ada di 11 Kabupaten/Kota. kepastian waktu kematian terhadap larva nyamuk Aedes agypti.

http://www.depkes.go.id/article/view/160 20900001/wilayah-klb-dbd-ada-di-11kabupaten-kota.html. Diakses pada 12 April 2016.

Kementerian Kesehatan Republik Indonesia. Peraturan Menteri Kesehatan RI. 2016.b Kendalikan DBD dengan PSN 3M Plus, http://www.depkes.go.id/article/view/160 20900002/kendalikan-dbd-dengan-psn3m-plus.html. Diakses pada 27 Februari 2016.

Maryam.S. 2009. Ekstrak Enzim Bromelin Dari Buah Nanas (Ananas sativus Schult.) Dan Pemanfaatan Pada Isolasi DNA. Jurnal Online Digilib Unnes. https://lib.unnes.ac.id/2460/1/4628.pdf.

Diakses pada 1 Januari 2017.

Murniati, E., 2006. Sang Nanas Bersisik Manis di Lidah. Percetakan SIC. Surabaya.

Oktaviani R, Rahayu K dan Suhartatik N. 2016. Pemanfaatan Limbah Nanas (Ananas comosus L. Merr) Pada Pembuatan Kecap Ikan Lele (Clarias sp) Dengan Variasi Lama Fermentasi. Jurnal Jitipari, 2 (1), 1-10. https://ejurnal.unisri.ac.id/index.php/jtpr/ article/view/1526

Peraturan Menteri Kesehatan RI nomor 374/Menkes.Per/III/2010 tentang Pengendalian Vektor. http://perpustakaan.litbang.depkes.go.id/l okaciamis/index.php?p=show_detail\&id= 1042. Diakses pada 29 Februari 2016.

Silaban, I dan Rahmanisa,S. 2016. Pengaruh Enzim Bromelin Buah Nanas (Ananas comosus L.) terhadap Awal Kehamilan. Medical Journal of Lampung University (Majority), 5 (4) . 80-85. Retrieved from http://juke.kedokteran.unila.ac.id/index.p hp/majority/article/view/889/797.

Supartono. 2004. Karakterisasi Enzim Protease Netral dari Buah Nenas Segar. Jurnal MIPA Universitas Negeri Semarang 27 (2): 134-142.

Tamza RB, Suhartono, Darminto. 2013. Hubungan Faktor Lingkungan dan Perilaku dengan Kejadian Demam Berdarah (DBD) di Wilayah Kelurahan Perumnas Way Halim Kota Bandar 
Lampung. Jurnal Kesehatan Universitas Diponegoro, 2 (2).

Wibisono Wahyu Gunawan. 2011. Tanaman Obat Keluarga Berkhasiat. Ungaran. Jawa Tengah: Vivo Publisher.

Wuryanti. 2004. Isolasi dan penentuan aktivitas spesifik enzim bromelin dari buah nanas (Ananas comosus L.). Jurnal Kimia, Sains dan Aplikasi. 7 (3), 78 - 82. https://ejournal.undip.ac.id/index.php/ksa /article/view/3327

Wuryanti. 2006. Amobilisasi Enzim Bromelin dari Bonggol Nanas dengan Bahan Pendukung (Support) Karagenan dari Rumput Laut (Euchema cottonii). Jurnal Kimia, Sains dan Aplikasi, 9 (3), 55-59. https://ejournal.undip.ac.id/index.php/ksa /article/view/3284. 